\title{
Double Role of Dancers in the Rampak Terbang Dance
}

\author{
Yogi Hadiansyah*, Juju Masunah, Trianti Nugraheni \\ Art Education Program \\ Universitas Pendidikan Indonesia \\ Bandung, Indonesia \\ *yogihadiansyah81@gmail.com
}

\begin{abstract}
This study aims to analyze the pattern of rhythmic musical Gembrung Terbangan in the presentation of the Terbang Gede Music which is used as inspiration for the development of movements in the presentation of the Rampak Terbang Dance. The tempo, dynamics, beat, and rhythm patterns in the musical playing of the Gembrung Terbangan are used as the basis for the creation of the Rampak Terbang dance movements. This research uses ethnochoreology approach with descriptive analysis method. The research data were obtained from the results of an interview with the Rampak Terbang Dance's choreographer, study documentation of the Rampak Terbang dance videos. The findings of this study are: 1). The dancers in Rampak Terbang dance have two artistic abilities, namely the musical dan movement; 2). Management of double role in the Rampak Terbang dance performance. In conclusion, Rampak Terbang Dance conveys religious messages throught the packaging of the ethical and aesthetic values in the synergy between the rhythm of musical Gembrung Terbangan and the movements of the Rampak Terbang dance.
\end{abstract}

Keywords—double roles, musical abilities, movement abilities, Rampak Terbang Dance

\section{INTRODUCTION}

The existence of dance and music in the presentation cannot be separated [1-3]. This is like what is found in the performing arts of rampak terbang Dance. Rampak terbang dance is a new creation dance that combines Rudat art with Terbang Gede music. This rampak terbang dance develops in Serang City and is used as an offering dance or a welcome dance at Senior High School in Serang, Banten. This dance is inspired by student activities and school activities with religious nuances. This dance, which is thick with Islamic religious nuances, shows the identity of the strong Islamic beliefs of the local community which is visualized through dance works [4-6].

In its presentation, we can understand an element of music and dance as an integral part which is closely related [2,7-9]. The problem of dance and music is always associated with the basic elements in it, such as the rhythmic element as an element of musicality which becomes a stimulus for movement [10-13]. Even in the presentation of music, the existence of movement is a part that shows the strengthening of the expression of the musical game being played [14-18].

The form of the presentation of the rampak terbang dance is packaged with terbangan musical instruments with Islamicinspired lyrics as a medium of preaching in which there are praises to Allah SWT and the Prophet as a form of expression of gratitude for the religious people of Serang City. This kind of dance is a dance offering that has the values of Islamic teachings [19].

Rampak terbang dance is a form of creative dance rooted in local cultural wisdom [20]. Dances that have Islamic nuances are not only visible in the form of movement and music, other elements can also be observed such as elements of make-up and clothing [21]. All elements of the presentation of the rampak terbang dance have the power to carry Islamic values.

One of the uniqueness contained in the presentation of the rampak terbang dance is the existence of dancers who have two different roles that are displayed at the time of the show, namely the role of a dancer and a music player. The dancers role emerged is when demonstrating the aesthetic and meaningful movements that are displayed in the presentation of the rampak terbang dance, while the role of a musician is emerged when collaborating with the beats of the terbang instrument which is performed directly by the dancer.

The purpose of writing this article is to describe the double roles of a rampak terbang dancer as well as a gembrung terbangan music player. Therefore, the researcher tried to study the gembrung Terbang Music formulation in the rampak terbang Dance, which performed a double role, a dancer as well as musical instrument player.

\section{RESEARCH MethodOLOGY}

This study uses a qualitative paradigm, with an ethnocoreological approach. The method used is descriptive analysis. The use of descriptive analysis method aims to provide an accurate description of facts and phenomena in the field with regard to the study of the Gembrung terbang Music pattern in the creation of the rampak terbang dance [22] 
The data research were obtained from the results of interviews with the rampak terbang dance creators of the and studies on fhotografy and video documentation of rampak terbang dance and music performance that has bean researched $[23,24]$. Dance movements were analyze by triangulasi which is compare the interview result and documentation and literature studies for the further interpretation.

\section{RESEARCH RESULTS AND DISCUSSION}

\section{A. Islamic Elements in Rampak Terbang Dance}

The rampak terbang dance is a dance that is accompanied by a rampak terbang gede musical instrument, which tells about the daily life of a student. The birth of the rampak terbang dance, is an actualization of the dance creator who describes the real area and conditions of society. This dance can be categorized as a dance that has a ceremonial function because it is performed as an offering dance.

This ceremony is a process of expressing gratitude to Allah SWT to be defend in the Progress of the Times. In the process, of creation terbangan pattern is played by a group of men when parading becomes the basic idea of this dance. the verses of sholawatan and tabuh patterns have their own characteristics. In addition, tolerancy with other communities helping each other, giving each other, sincerely and doing it together.

The outfit of the Rampak terbang dance is to use a polite dance costume because it reflects that the rampak terbang dance is an Islamic dance with bright clothing colors. The choreography of the rampak terbang dance which is in line with the accompanying music is energetic, cheerful but still in a beautiful and polite dance position. It does not show negative elements of movement in the sense that this dance movement deserves to be seen by all audiens.

1) Religious value in the element of movement: The concept of movement that is worked out in the rampak terbang dance carries many forms of religious movements that describe worship to Allah. The forms of movement are deku salam, Nadrah Hyang Widi, Pasrah Sanghyang Widi, Tapakur Diri, and Pang Bagea Wilujeng.

Dance Movement is the main element as a medium for expressing the values and messages to be conveyed to the audience through the language of movement. In this case, the concept of presenting motion in the rampak terbang dance has values and messages in an effort to convey the desire of the dance stylists to give Islamic messages through the language of motion in the rampak terbang dance. worshiping to Allah is the only a value of the religious concept carried in the rampak terbang dance.
2) Religious value in music elements: The form of presentation rampak terbang dance in very Islamic because is supported by Islamic music and sholawatan song. Terbang is a type of striking musical instrument made of wood and animal skin that has gone through the refining process. The sound of the terbang musical instrument lies on a sheet of skin that is affixed to the circle of the top of the wood which is used as the basis for storing the skin.

The creator of the rampak terbang dance music, Ikhsan Gumilar, S.Sn, said that his work was inspired by the terbang patterns, kosidah and bedug patterns that has bean developing in Banten Province. The element of prayer is domination in this rampak terbang dance. The musical instruments are using: terbang gede, rudat, tumbuk, hajir, markis, bedug, cymbal and gong.

The musical instrument used is similar to the gembrung music pattern. Gembrung is an art that integrates the tradition of reciting shalawat with the accompaniment of terbang music collaborated with gamelan and kendang as well as the rhythm of traditional gending songs as a local cultural art.

Gembrung is the name of the rampak bedug pattern typical of Pandeglang city. Bedug instruments, especially bedug gede, when beaten produce a loud and echoing sound. With a sound like that, the public heard a bedug sound like it echoed from a distance. Thus, it is called the gembrung or echoing pattern.

The gembrung pattern in rampak terbang dance has a melodic and repeated rhythm. In the rhythm of the melody, it then forms a percussion pattern. Relationships are formed from the elements that make up the relation, such as the sixteenth note and the second third note in the first beat consisting of four notes with the following note relations and so on. After that, it forms an identity that the melodic rhythm played with the rhythm is a percussion pattern.

The syntagmatic relationship in the gembrung pattern is from a note with notes that can be in front of it or behind it in a big melodic rhythm, such as in the first beat, which consists of three one-sixteenth notes and one third-second note that sounds dong on the line the first (sixteenth note) and the second note sounding dong (third-second note) and two sixteenth notes which sound dong and tung in the first and second lines. Then the second beat and so on the melody is repeated to the end like the first beat [25].

From this series of notes a melody can be formed which is called the "gembrung" percussion pattern so that the relationship of one note to another creates a unique melody sequence. Terbang beat notation can be seen in figure 1 . 

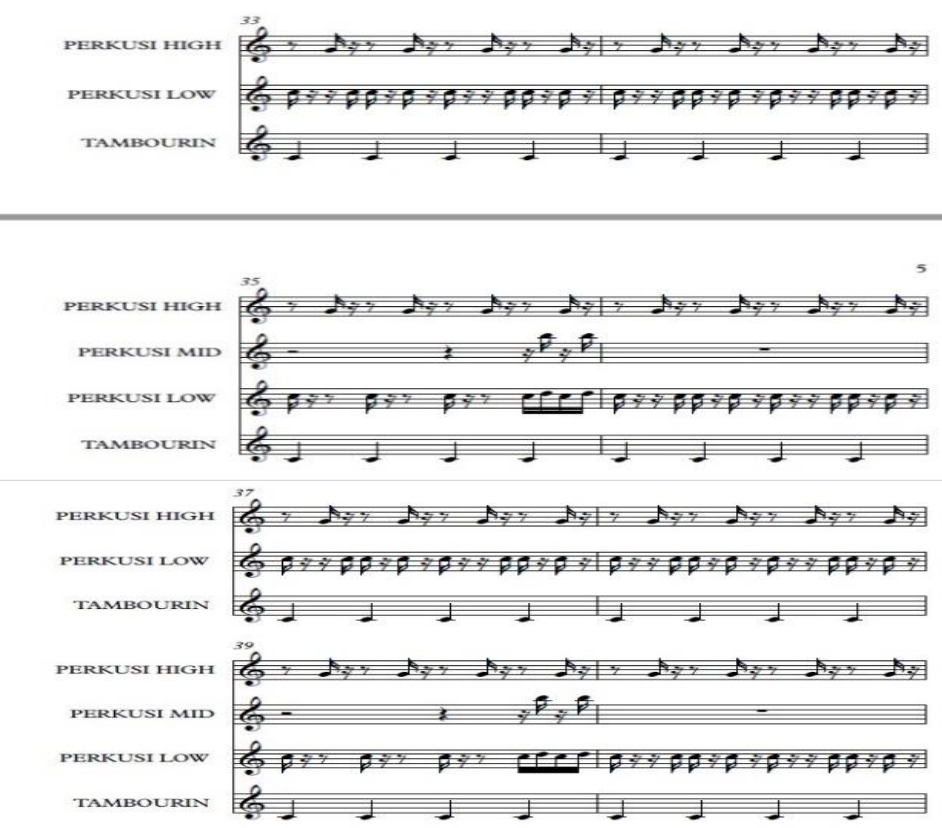

Fig. 1. Terbang beat notation.

The paradigmatic relationship in the tabuh gembrung pattern is the selection of notes from one note to another. The paradigmatic relationship in the tabuh gembrung pattern is vertical. This means that the first note sounds "dong", the next note must sound "dong" and so on, so that the selection of notes from the gamelan music pattern produces a melody called the gamelan drum pattern.

This Javanese percussion pattern is also usually the music used in major Islamic religious events. So that this gembrung is known to have a load of religious values and noble character contained in the verses of art called sholawatan gembrung [26]. This gembrung pattern is a suitable combination with the rampak terbang dance. In addition, when the dancer performs, the dancer brings dance properties, namely an ancak besi in the shape of a cross resembling the letter $X$ and 2 pieces of rebana or rudat and 2 drum sticks. This makes the flying appearances dance look lively and neat.

3) Religious value in the element of outfit: The rampak terbang dance is a dance performance as well as music. Presented in groups, performed energetically and dynamically, by women. The harmonization of movement and music is carefully adjusted, the chanting of sounds, movements and supported by dance properties bring a religious atmosphere, as a form of local wisdom in the City of Serang-Banten.

The strength of religious values in the rampak terbang dance is not only seen from the elements of motion and elements of music. But it can also be seen from the elements of the outfit worn by the dancers. The outfit worn by dancers in the rampak terbang dance basically uses the concept of female Muslim outfit with the basic use of the hijab outfit element for the head and long Muslim clothes. The concept of presenting the musilm clothing used in the rampak terbang dance is more reflective of the type of clothing worn by Muslim women in accordance with the provisions of Islamic law, intended to cover body parts that are not suitable to be shown to the public.

\section{B. Role and Ability of Dancers as Dancers}

This dance is a group dance with 5 dancers or more. There are thirty-two movements created in the rampak terbang Dance. Each movement has its own unique name. The structure of the movement in the presentation of the rampak terbang Dance is a category as a dancer who has Islamic nuances as follows (table $1)$.

TABLE I. MOVEMENT StRUCTURE OF RAMPAK TERBANG DANCE

\begin{tabular}{|c|c|c|}
\hline No. & Movement Name & Meaning of movement \\
\hline 1. & Duduk Deku Salam & $\begin{array}{l}\text { This movement describes about the } \\
\text { activity to please the guest as as well as to } \\
\text { pray. }\end{array}$ \\
\hline 2. & Sembah Salam & $\begin{array}{l}\text { This movement describes about the } \\
\text { activity to honour the guest and to ask } \\
\text { god's leave. }\end{array}$ \\
\hline 3. & Salam Dangu & $\begin{array}{l}\text { This movement describes about the } \\
\text { activity to answer the guest greeting loudly }\end{array}$ \\
\hline 4. & $\begin{array}{l}\text { Nadah } \\
\text { Nyantrik }\end{array}$ & $\begin{array}{l}\text { This movement describes the happiness in } \\
\text { wecoming the guest }\end{array}$ \\
\hline 5. & $\begin{array}{l}\text { Beber } \\
\text { Nadrah }\end{array}$ & $\begin{array}{l}\text { This movement describes about to honor } \\
\text { the guest and gods by charity sholawat }\end{array}$ \\
\hline 6. & $\begin{array}{l}\text { Nyantrik Dangu } \\
\text { Nadah }\end{array}$ & $\begin{array}{l}\text { This movement describes the human being } \\
\text { attitude. }\end{array}$ \\
\hline
\end{tabular}

The religious concept in the rampak terbang dance can be seen from several aspects of working elements, namely the concept o movement, music, and clothing. The three elements of the presentation of the rampak terbang dance have a 
religious concept which is visualized in the language of motion, music and clothing of the rampak terbang Dance.

One of the duties of a dancer is to bring dance materia that is suitableswith the theme and concept. Likewise, dancers in this flying dance performance have the duty and responsibility of being able to present dance materialsuitables to of the creator's idea, one of them.

Another ability that must be demonstrated by a dancer is being able to present the dance charachter. Thisstep is not easy for dancer because it requires a process of deepening the character or theme. This aspect is usually related to the theme, storyline and atmosphere built into the dance. This rampak terbang dance, dancer must be able to present dance material that has Islamic nuances that carry religious values and functions.

The 32 movements that are displayed in this rampak terbang dance show the dancers' duties and roles to be able to master all the motion materials in accordance with the dramatic structure of the movement.

\section{Role and Ability of Dancers as Music Players}

The movement structure in the presentation of Rampak Terbang Dance is a category as a dancer as well as a music player who has Islamic nuances as follows (table 2).

TABLE II. MOVEMENT STRUCTURE OF RAMPAK TERBANG DANCE

\begin{tabular}{|l|l|l|}
\hline No. & Movement Name & \multicolumn{1}{c|}{ Meaning of movement } \\
\hline 1. & $\begin{array}{l}\text { Gembrung } \\
\text { Terbangan }\end{array}$ & $\begin{array}{l}\text { In this movement the dancers the move to } \\
\text { get the terbang to serve to the guest (pure } \\
\text { movement). }\end{array}$ \\
\hline 2. & Yasalam & $\begin{array}{l}\text { In this movement the dancer follow the } \\
\text { terbangan music instrument to give first } \\
\text { service for the guest. (pure movement) }\end{array}$ \\
\hline 3. & Nandak Kanan kiri & $\begin{array}{l}\text { In this movement the dancer move to their } \\
\text { position for another floor pattern. While } \\
\text { stay focus to the guest. (Locomotor). }\end{array}$ \\
\hline 4. & Nadrah Pang Bagea & $\begin{array}{l}\text { In this movement the dancer move to their } \\
\text { position for another floor pattern. While } \\
\text { stay focus to the guest. (Locomotor). }\end{array}$ \\
\hline
\end{tabular}

The combination of dance is not only through body movements, but through the media of sound as is done in the rampak terbang dance. This dance has a unified link between content and form, which can be seen a groove that demands strength details, both from the arrangement of motion, time, rhythm, tempo, floor and space patterns. In these dances appear to have varied rhythms, namely slow motion, moderate movement and fast movement. Each dancer will move according to his own rhythm and tempo. This is in line with the opinion that there is a solidarity between the players, it is necessary to have a metronome that starts slowly then increases according to speed while the dancer maintains technique and movement harmony [27-29].

In the 19th movement the dancers began to take advantage of properties, namely iron ancak, tambourine, and stikt. $\mathrm{N}$ this time, the dancers began to make beats that made the dance festive. The beats are carried out simultaneously so that they make gembrung sound or echoing sound. Dancers perform in harmonious manner to enliven andto give spirite to the audience. This section shows the dual role of the dancer not only to have the ability to demonstrate movements in accordance with the structure of the dance work, but also to have other abilities in playing musical instruments that are used directly as dancers' properties.

Dance and music have the same position as elements of art which are used as a medium to communicate all messages that you want to convey to others [30-32]. In this context, the dancer must be able to play the role of a musician so that the message to be conveyed through the language of the sounds of musical instruments and human voices can be conveyed to the audience.

Basically, the problem of rhythm in music with humans is that there is an approach of homology and homoplation [30,33]. This approach provides a basic learning belief for each individual to be able to learn music, including the role of a dancer in mastering musical material. This is as shown by the rampak Terbang dance, dancers who are able to play flying musical instruments in processing musical elements in the presentation of the rampak terbang dance. In this case, a dancer is required to have a strong sense of musicality to be able to play a flying musical instrument in accordance with the rhythm pattern that is played.

In its presentation, it is not only rhythm patterns that dancers must play and master, but the dynamic aspect must also be an important aspect for dancers to master. Because in the presentation of the rampak terbang dance, the dynamic aspects of the music are thoroughly explored to create a dynamic that is not monotonous. The dynamics and tempo in music are often able to provide certain characters, making the presentation more interesting [34,35]. In this section, a Rampak terbang dance, dancer must be able to play the tempo and dynamics of playing a musical instrument and a sense of the musicality of dancing in accordance with the dramatic structure of the performance.

\section{CONCLUSIONS}

The Rampak Terbang dance is packed with terbangan musical instruments with Islamic-inspired lyrics. This will convey a message or story from the dance, in accordance with the religious identity of the city of Serang-Banten. The skill of rampak terbang dancers combining movements and music is a unique innovation in the art field. The idea of motion developed in the presentation of the rampak terbang dance explores the rhythmic patterns of the gembrung music which are transformed into the form of motion based on the development of counting patterns, dynamic patterns and variations of motion adapted to the rhythm of the gembrung terbangan music being played. Ethical and aesthetic values become one creating synergy between the rhythm of the gembrung terbangan music and the rampak terbang dance. 


\section{REFERENCES}

[1] A. Sanger, "Music and musicians, dance and dancers: socio-musical interrelationships in Balinese performance," Yearb. Tradit. Music, vol. 21, pp. 57-69, 1989.

[2] S. Nannyonga-Tamusuza, "Music as dance and dance as music: Interdependence and dialogue in Baganda Baakisimba performance," Yearb. Tradit. Music, vol. 47, pp. 82-96, 2015.

[3] I. Fedun, "Correlations between musicians and listeners in traditional instrumental music," Tiltai. Pried., no. 21,pp. 70-74, 2004

[4] L.I. Al Faruqi, "Dance as an expression of Islamic culture," Danc. Res. J., vol. 10, no. 2, pp. 6-13, 1978 .

[5] A.L. Kaeppler, "An introduction to dance aesthetics," Yearb. Tradit. Music, vol. 35, pp. 153-162, 2003.

[6] A. Shay, "Dance and non-dance: patterned movement in Iran and Islam,” Iran. Stud., vol. 28, no. 1-2, pp. 61-78, 1995.

[7] J. Torp, "Musical Movement: Towards a Common Term for Music and Dance," Yearb. Tradit. Music, vol. 45, pp. 231-249, 2013.

[8] S. Johnson, "Step dancing to hip hop? Reconsidering the interrelationship between music and dance in the Ottawa Valley step dancing community," Crossing Over, 2010.

[9] L. Felföldi, "Connections between dance and dance music: Summary of hungarian research,” Yearb. Tradit. Music, vol. 33, pp. 159-165, 2001.

[10] T.O. Izim, K.Z. Usenuly, B. Turgymbaeva, M.S. Saukhanova, K.U. Kariyeva and Z.M. Baigozhina, "On the professional competence formation in students as future choreography teachers (based on the art history materials of choreography of Kazakhstan)," Rev. Espac., vol. 39, no. 21, 2018.

[11] L. Svobodová, A. Skotáková, P. Hedbávný, P. Vaculíková, and M. Sebera, "Use of the dance pad for the development of rhythmic abilities," Sci. Gymnast. J., vol. 8, no. 3, pp. 283-293, 2016.

[12] L.F. Chiat and L.F. Ying, "The perception of dancers on the congruence between music and movement in a rhythmic gymnastics routine," Life Sci. J., vol. 11, no. 6, 2014.

[13] L.F. Chiat and L.F. Ying, "Visual perception of phrasing in a tai chi routine using different music accompaniments," Procedia-Social Behav. Sci., vol. 174, pp. 3044-3048, 2015.

[14] M. Nusseck and M.M. Wanderley, "Music and Motion-How MusicRelated Ancillary Body Movements Contribute to the Experience of Music," Music Percept., vol. 26, no. 4, pp. 335-353, 2009.

[15] P.E. Keller and M. Appel, "Individual differences, auditory imagery, and the coordination of body movements and sounds in musical ensembles," Music Percept., vol. 28, no. 1, pp. 27-46, 2010.

[16] B. Caramiaux, F. Bevilacqua, and N. Schnell, "Towards a gesture-sound cross-modal analysis," in International Gesture Workshop, 2009, pp. $158-170$.

[17] F. Desmet, L. Nijs, M. Demey, M. Lesaffre, J.-P. Martens, and M. Leman, "Assessing a clarinet player's performer gestures in relation to locally intended musical targets," J. New Music Res., vol. 41, no. 1, pp. $31-48,2012$.
[18] A.P. Demos, R. Chaffin, and V. Kant, "Toward a dynamical theory of body movement in musical performance," Front. Psychol., vol. 5, p. 477, 2014

[19] N.A.B. Zakaria, N. Salleh, Z.Ab Rahman, W.H. Khairuddin, and A.Y.M. Noor, "As-Sama'Dhikr Dance: An Analysis Based On The Views Of Islamic Scholars," Int. J. Civ. Eng. Technol. (IJCIET). IAEME Publ., vol. 9, no. 8, pp. 1132-1139, 2018.

[20] I. Istiqomah and H. Habudin, "Analisis Nilai-Nilai Pendidikan dalam Seni Tari Ahlan Wasahlan dan Tari Rampak Terbang Ciolang Daerah Banten,” Prim. J. Keilmuan dan Kependidikan Dasar, vol. 10, no. 02, pp. 135-148, 2019

[21] H. Siswantari and F. Setyaningrum, "Adaptation of Islamic Dance Art Education in the Higher Education of Islam, Yogyakarta," ICLI 2018, p. 90, 2019.

[22] D. Sugiyono, "Metode penelitian kuantitatif dan R\&D," Bandung Alf., 2010

[23] A. Indrawan, "Selawatan Sebagai Seni Pertunjukan Musikal," Resital J. Seni Pertunjuk. (Journal Perform. Arts), vol. 11, no. 2, 2010.

[24] W.D. Nugraha, "Harapan Manusia Atas Kekuatan Allah SWT dan Gaib Pada Rajah dalam Tradisi Terbangan Di Kabupaten Bandung." Universitas Pendidikan Indonesia, 2014.

[25] S. Rizal, "Struktur Pola Tabuh Rampak Bedug pada Sanggar Bale Seni Ciwasiat Kabupaten Pandeglang," Panggung, vol. 29, no. 4, 2019.

[26] R. Kurnianto, "Pola Sosialisasi Nilai Agama dan Budi Pekerti Berbasis Akulturasi Budaya Pada Selawatan Gembrung," El Harakah, vol. 14, no. 2, p. 206, 2012.

[27] P. Atkinson and M. Duffy, "Seeing movement: Dancing bodies and the sensuality of place," Emot. Sp. Soc., vol. 30, pp. 20-26, 2019.

[28] M. Hrubes, "Return-to-Dance Strategies and Guidelines for the Dancer," Perform. Arts Med., p. 139, 2018.

[29] T. Edensor and C. Bowdler, "Site-specific dance: revealing and contesting the ludic qualities, everyday rhythms, and embodied habits of place," Environ. Plan. A, vol. 47, no. 3, pp. 709-726, 2015.

[30] E.H. Hagen and G.A. Bryant, "Music and dance as a coalition signaling system,” Hum. Nat., vol. 14, no. 1, pp. 21-51, 2003.

[31] R. BliegeBird, E. Smith, M. Alvard, M. Chibnik, L. Cronk, L. Giordani, and E. Smith, "Signaling theory, strategic interaction, and symbolic capital," Curr. Anthropol., vol. 46, no. 2, pp. 221-248, 2005

[32] S. Koelsch and W.A. Siebel, "Towards a neural basis of music perception," Trends Cogn. Sci., vol. 9, no. 12, pp. 578-584, 2005.

[33] J. Phillips-Silver, C.A. Aktipis, and G.A. Bryant, "The ecology of entrainment: Foundations of coordinated rhythmic movement," Music Percept., vol. 28, no. 1, pp. 3-14, 2010.

[34] H. Takeda, T. Nishimoto, and S. Sagayama, "Rhythm and tempo recognition of music performance from a probabilistic approach," 2004.

[35] A. Lerch, C. Arthur, A. Pati, and S. Gururani, "Music Performance Analysis: A Survey,” arXiv Prepr. arXiv1907.00178, 2019 